\title{
Preparation of nanowires based on the tobacco mosaic virus and gold nanoparticles
}

\author{
V.L.Karbivskyy, N.A.Kurgan, V.Kh.Kasyanenko, \\ Yu.A.Lukyanenko, L.I.Karbovskaya
}

\author{
G.Kurdyumov Institute for Metal Physics, National Academy of Sciences \\ of Ukraine, 36 Vernadsky blvd., 03680 Kyiv, Ukraine
}

Received December 8, 2014

\begin{abstract}
The technique of producing nanowires based on TMV and gold nanoparticle, which consists of multiple cycles of sequentially adding the metal source, viruses and reduced agent, was developed. A study carried out of the physicochemical properties and the morphology of the nanowires obtained by atomic force microscopy and X-ray photoelectron spectroscopy "angular resolution". It was found that the resulting hybrid virus-inorganic structure prefer to cluster ordering. Interaction nanowires with the substrate characterized $\mathrm{C}-\mathrm{N}$ bond. Bond $\mathrm{N}-\mathrm{C}=\mathrm{O}$ characterized binding virions with each other.
\end{abstract}

Keywords: nanowires, tobacco mosaic virus, gold nanoparticles, atomic force microscopy.

Разработана методика получения нанопроводов на основе вируса табачной мозаики и наночастиц золота, которая состоит из нескольких циклов последовательного добавления источника металла, вирусов и восстановителя. Проведено исследование физикохимических свойств и морфологии полученных нанопроводов методами атомно-силовой микроскопии и рентгеновской фотоэлектронной спектроскопии с "угловым разрешением". Установлено, что полученные гибридные вирус-неорганические конструкции предпочитают кластерное упорядочение. Взаимодействие нанопроводов с подложкой характеризует связь $\mathrm{C}-\mathrm{N}$, связь $\mathrm{N}-\mathrm{C}=\mathrm{O}$ характеризует связь вирионов друг с другом.

Отримання нанодротів на основі вірусу тютюнової мозаӥки та наночастинок золота. В.Л.Карбівський, Н.А.Курган, В.Х.Кас'яненко, Ю.А.Лук'яненко, Л.І.Карбовська.

Розроблено методику отримання нанодротів на основі вірусу тютюнової мозаїки та наночастинок золота, яка складається з декількох циклів послідовного додавання джерела металу, вірусів і відновника. Проведено дослідження фізико-хімічних властивостей і морфології отриманих нанодротів методами атомно-силової мікроскопії та рентгенівської фотоелектронної спектроскопії з "кутовою роздільною здатністю". Встановлено, що отримані гібридні вірус-неорганічні конструкції надають перевагу кластерному впорядкуванню. Взаємодію нанодротів з підкладкою характеризує зв'язок $\mathrm{C}-\mathrm{N}$, зв'язок $\mathrm{N}-\mathrm{C}=\mathrm{O}$ характеризуе зв'язок віріонів один з одним.

\section{Introduction}

One of the intractable problems in the field of nanotechnology is to produce nanoobjects of the same shape and size. To solve this problem, the most promising is the use of tobacco mosaic virus (TMV) [1]. TMV can be chemically and genetically modified to varying physical properties and it adaptation to specific applications. Currently in the world conduct research for the use of TMV in the production of nanowires, nanostructured thin films, biomimetic surface sensors, microbatteries high performance, solid-state nanoelectronics and biosystems engineering. The intensity of these studies due to the fact that the area of microelectromechanical systems is constantly evolving and allows more efficient miniaturized 


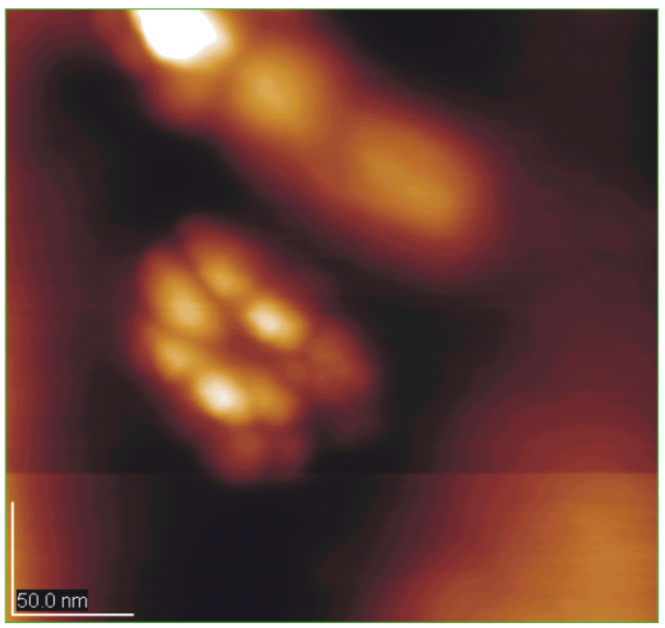

a)

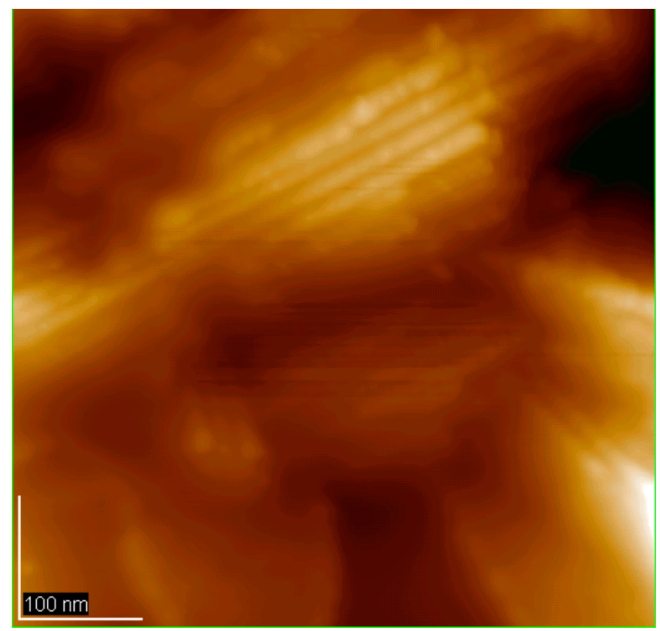

b)

Fig. 1. AFM image of nanoparticles of Au (a) and nanowires Au-TMV (b).

the functional devices and integrated systems [2-6]. However, the fundamental limitations of microtechnology not allow to go beyond certain dimension limits. Therefore, the integration of nanostructured materials into functional devices remains a challenge that can not be solved by standard methods and materials [7-9].

Tobacco mosaic viruses have a characteristic structure which is similar to nanocables - hollow proteinaceous tube which extends inside the "wiring" of the RNA. Length virus is $300 \mathrm{~nm}$, external diameter - $18 \mathrm{~nm}$, and the inner cavity has a diameter of $4 \mathrm{~nm}$. Virus capsid consists of 2130 protein molecules (monomers) turning of spiral around the RNA strand. Monomer of the protein consists of 158 amino acid residues [10]. TMV heat resistant virus. It can withstand $60^{\circ} \mathrm{C}$ for $30 \mathrm{~min}$.

Advantages of the use of TMV are as follows: all of one type TMV particles are identical in structure, shape and size; virions (mature viruses) TMV can exercise self-assemble and form organized structures defined, for example, the chain connecting the ends; they are very stable both chemically and physically, and, finally, they may be coated metal, silica and semiconductor materials [11-15].

The surface of the virus is composed of repetitive amino acid chains. The inner cavity preferably consists of glutamic and aspartic acid, as the outer surface is composed of a large number of lysine and agrinin radicals. This fact suggests that the surface of the virus to be reacted with metal nanoparticles (gold, silver) [12-14, 16-18].
Attaching various nanoparticles to the virus molecules can be controlled by altering the chemical environment interaction ( $\mathrm{pH}$, presence of oxidation / reducing agent) [19-21].

\section{Materials and methods}

For nanowires preparation were developed a new method based on citrate method synthesis of metal nanoparticles [22] and includes the preparing of the metal source and reductant stock solutions and the gold recovery process through several cycles of mixing solutions, in the presence of the purified and modified TMV. The procedure involves the following steps: preparing a stock solutions $\mathrm{KAuCl}_{4}$ and $1 \%$ $\mathrm{Na}_{3} \mathrm{C}_{6} \mathrm{H}_{5} \mathrm{O}_{7} \cdot 2 \mathrm{H}_{2} \mathrm{O}$ and obtaining of colloidal gold via addition of the sodium citrate solution to the boiling solution of potassium tetrachloroaurate in a ratio of $20 \mathrm{ml}$ of $1 \mathrm{mM} \mathrm{KAuCl}{ }_{4}+2 \mathrm{ml} 1 \% \mathrm{Na}_{3} \mathrm{C}_{6} \mathrm{H}_{5} \mathrm{O}_{7} \cdot 2 \mathrm{H}_{2} \mathrm{O}$ in several stages and stirring until the red color. In the first step, after addition of sodium citrate were added purified TMV viruses. At the end of the procedure, after the last stage, the sodium borohydride $\mathrm{NaBH}_{4}$ was added as the reducing agent. The choice of procedure for the recovery of gold a few cycles due to the fact that usually the virus particles were incubated with $\mathrm{KAuCl}_{4}$ from $30 \mathrm{~min}$ to three hours, hoping that this time anions $\left[\mathrm{AuCl}_{4}\right]^{-}$will be located near the positively charged amino acids on the virion surface, and then spend the recovery of gold the addition of $\mathrm{NaBN}_{4}$. However, considering the fact that the mechanism of the nanowire formation consists of piecemeal self-assembly process of 


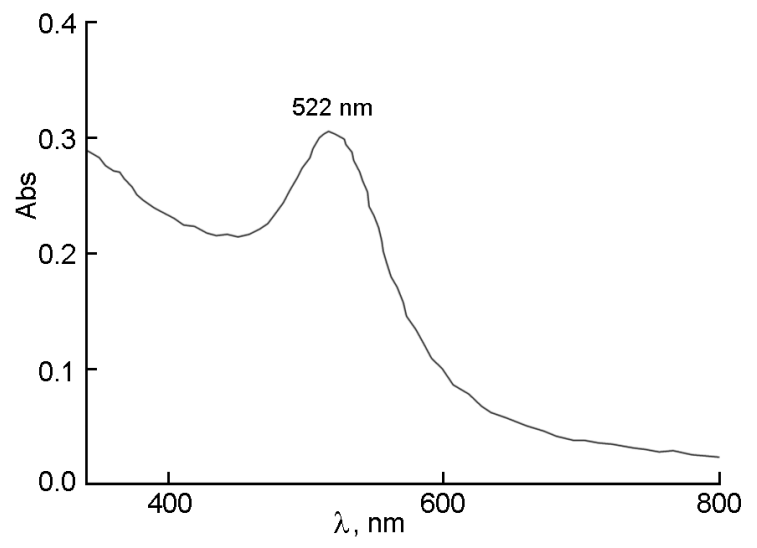

Fig. 2. The optical spectrum of Au nanoparticles.

the gold nanoparticle on the surface of the tobacco mosaic virus due to the appearance of a potential difference, the recovery of gold in several cycles (the optimum number of cycles 5-7) enabled not only reduce time incubation of virions to 7-12 $\mathrm{min}$ for one cycle, but also to avoid bio-induced gold recovery (before adding the reducing agent) and as a result, the formation of larger nanoparticles.

To avoid clumping nanoparticles used ethanol, which was added after the first cycle.

The size of the nanoparticles after the fifth cycle was approximately $15-20 \mathrm{~nm}$ (Fig. 1a). The hybrid bioinorganic virallygold structure was about $50 \mathrm{~nm}$ in diameter and 150-400 $\mathrm{nm}$ in length. Uncoated gold TMV virions were not detected (Fig. 1b).

We used the tobacco mosaic virus solution in water, a concentration of $200 \mathrm{mg} / \mathrm{ml}$. At room temperature, viruses tend to stick together, to avoid this, immediately before the experiment they were treated in an ultrasonic bath at ultrasonic frequency - $50 \mathrm{kHz}$, time of exposure $30 \mathrm{~min}$ and the temperature $-30^{\circ} \mathrm{C}$.

Studies of the nanorelief surface of nanowires was performed by atomic force microscopy (AFM) on the instrument JSPM4610 (Jeol, Japan). The vacuum chamber of an atomic force microscope was not lower than $10^{-7} \mathrm{~Pa}$. The studies were conducted at room temperature. Surface temperature drift does not exceed $0.05 \mathrm{~nm} / \mathrm{s}$. For a given size of the studied areas it had no effect on the results.

X-ray photoelectron spectra of the core levels of the elements were obtained by XPS system for JSPM-4610 (Jeol, Japan). Operating vacuum during the experiment was $10^{-7} \mathrm{~Pa}$. Magnesium anode with an energy line $\mathrm{MgK}_{\alpha} 1253.6 \mathrm{eV}$ was used. Energy reso-

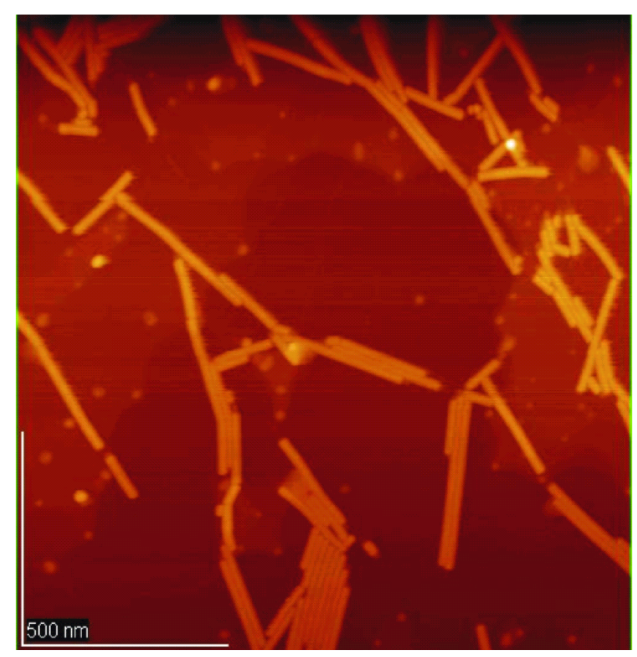

Fig. 3. AFM image of Au-TMV nanowires on a silicon single crystal.

lution is $0.1 \mathrm{eV}$. Calibration was carried out on the binding energies of Au $4 f$-line $87.5 \mathrm{eV}$. After receipt of the X-ray photoelectron spectra with "angular resolution", the angle $\varphi$ between the normal of the sample and X-ray beam was $0^{\circ}$ and $\pm 30^{\circ}$.

Spectrophotometric study of the colloidal solution of gold nanoparticles were performed on a single-beam spectrophotometer Spekol 1500 (Jena, Germany) in the wavelength range 190-1100 $\mathrm{nm}$.

\section{Results and discussion}

For more accurate particle size were carried out spectrophotometric study of the colloidal solution of gold nanoparticles obtained if all the conditions described method, excluding the presence of TMV. Studies have shown a surface plasmon resonance of gold nanoparticles at a wavelength of $522 \mathrm{~nm}$, which corresponds to a particle size of 15-20 nm and confirmed by studies by atomic force microscopy (Fig. 1a, 2).

After obtaining, the samples of Au-TMV nanowires were examined by atomic force microscopy using cantilever with diamond tip NSG-10-DLC, it possible to obtain images with a maximum resolution (Fig. 3, 4).

Fig. 3-4 shows the AFM image of the accumulation of virus, coated gold nanoparticles. A general trend of ordering virus in the clusters was observed after applying the metal nanoparticles to the viruses surface. The aspiration system to reduce the surface energy leads to activation of the aggregation processes: coagulation and coalescence of nanowires TMV-Au, the result of which is to the ordering and accumulation of 

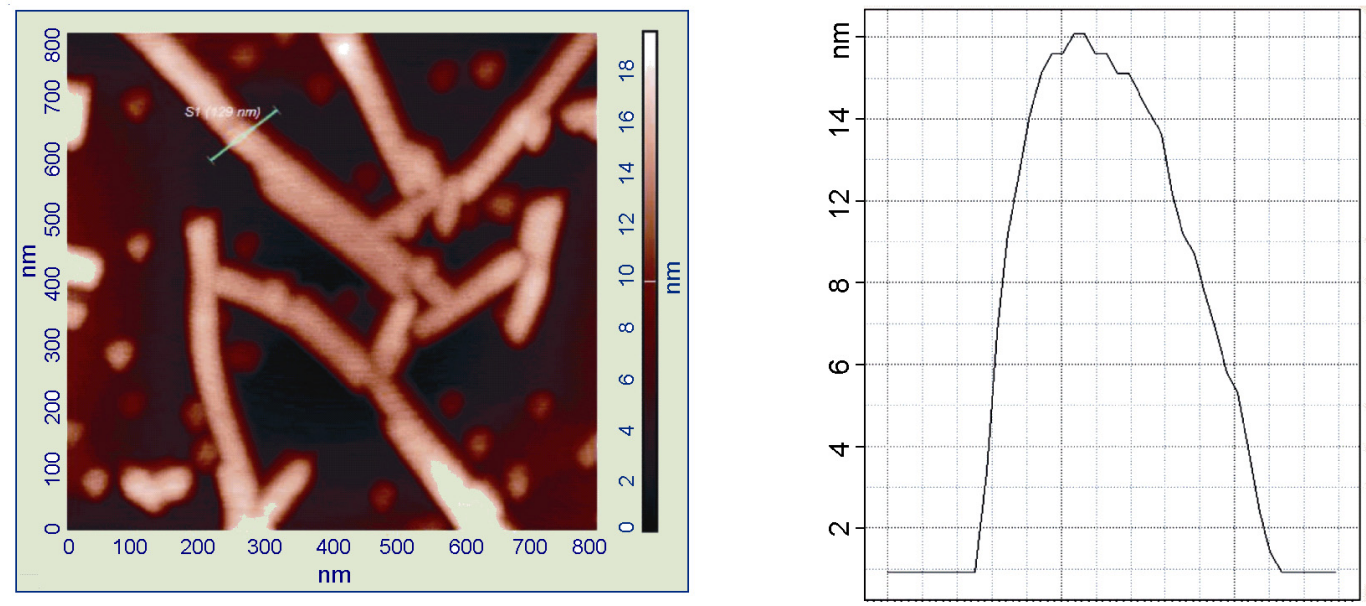

Fig. 4. Measure the height of nanowires Au-TMV through obtaining their profile.

nanowires, i.e. hybrid virus-inorganic structures have the property of self-assembly. In addition to the nanowires observed the presence of individual clusters of gold nanoparticles, the formation of which is also likely associated with the aggregation processes on a silicon surface.

To elucidate the effect of the silicon substrate to interact TMV with Au nanoparticles were obtained X-ray photoelectron spectra of C $1 s$ (Fig. 5).

Carbon spectra showed the different intensity of the two main features for the different angles of photoelectron yield. The main peaks of the spectra (Fig. 5, the spectrum 1) at $286.0 \mathrm{eV}$ characterized the interaction of $\mathrm{C}-\mathrm{N}$, that fact confirmed by the data of [23-25] and indicates to the interaction between the substrate and nanowires. The low-energy feature (about $284.0 \mathrm{eV}$ ) reflects the interaction of the $\mathrm{C}-\mathrm{C}$ and $\mathrm{C}-\mathrm{H}$ (Fig. 5, spectra 4-6), which are characteristic of interphase, but have an order of magnitude more intense than the signal from the substrate after ion etching. Accordingly, this feature appears due to the presence of virions, which applied to the surface. The presence of interaction between virions confirm the shift of the intensity, that characterized the $\mathrm{C}-\mathrm{N}$ interaction, towards higher energies by changing the angle of inclination of the sample up to $\pm 30^{\circ}$, which is associated with an increase in the contribution of surface atoms in the shape of the spectrum and reflects the interaction of $\mathrm{N}-\mathrm{C}=\mathrm{O}$, characterizing the virions bond with each other (Fig. 5, spectra 2-3).

The surface of the virion, as described above, has an electric charge is not compen-

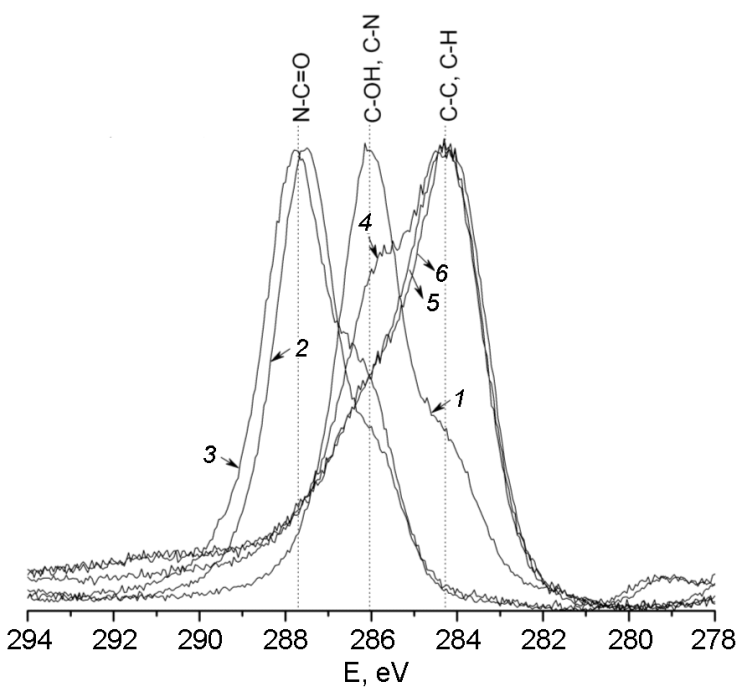

Fig. 5. X-ray photoelectron spectra of C $1 s$ TMV on $\mathrm{SiO}_{2}$ substrate: $1-\varphi=0^{\circ}, 2-\varphi=+30^{\circ}, 3-$ $\varphi=-30^{\circ}$. Etching of the sample $(1 \mathrm{kV}$; $20 \mathrm{~mA} ; 5 \mathrm{~min}): 4-\varphi=0^{\circ}, 5-\varphi=0^{\circ}, 6-$ $\varphi=+30^{\circ}$, where $\varphi-$ angle between the normal of the sample and the beam, which is subject to detection.

sated. The surface of the single crystal silicon is not charged, hence excluded Coulomb interaction. Since silicon does not create chemical bonds with either one of amino acids constituting TMV, chemical interaction are also eliminated because the most likely cause adsorption of virions to Si (111) has a van der Waals forces and hydrogen bonds. There are hydroxyl and carboxyl groups from the amino acid composition on the surface of virions. Therefore, it is likely that through the creation of hydrogen bonds between them and the surface of $\mathrm{Si}$ provided virus adsorption. 


\section{Conclusions}

A new method for producing nanowires by tobacco mosaic virus and gold nanoparticles which included the preparing a stock solutions of metal source and reducing agent and the gold recovery process through several cycles of mixing solutions, in the presence of the purified and modified TMV was developed. Nanowire obtained had a size of about $50 \mathrm{~nm}$ in diameter and 150$400 \mathrm{~nm}$ in length. The size of the gold nanoparticles in the final stage of synthesis was about $15-20 \mathrm{~nm}$.

It is established that, after application of metal nanoparticles on the surface of viruses has been a general trend of ordering virus in the clusters. The aspiration system to reduce the surface energy leads to activation of the aggregation processes: coagulation and coalescence of nanowires TMV-Au, the result of which is to the ordering and accumulation of nanowires.

Interaction nanowires with the substrate characterized $\mathrm{C}-\mathrm{N}$ bond. $\mathrm{N}-\mathrm{C}=\mathrm{O}$ bond characterized binding virions with each other. The adsorption of viruses is achieved by creating hydrogen bonds between them and the surface of Si.

The studies open up prospects of development domestic technologies for producing nanomaterials based on plant viruses and metal particles to produce materials for nanoelectronics and medicine (in particular, to create cheap memory chips, high-density recording, sensor elements for various applications, process control systems, transport biologically active components in medicine).

\section{References}

1. M.Sarikaya, C.Tamerler, A.Jen, Nature Mater., 2, 577 (2003).

2. K.Kordas, A.E.Pap, J.Vahakangas et al., Appl. Surf. Sci., 252, 1471 (2005).
3. J.H.Wang, P.Y.Su, M.Y.Lu et al., Electrochem. Solid-State Lett., 8, 9 (2005).

4. S.Sun, D.Yang, G.Zhang et al., Chem.Mater., 19, 6376 (2007).

5. B.Xiang, P.Wang, X.Zhang et al., Nano Lett., 7, 323 (2007).

6. L.Durrer, T.Helbling, C.Zenger et al., Sens. Actuators B, 132, 485 (2008).

7. D.Q.Zhang, J.Yang, Y.Li, Small., 9, 1284 (2013).

8. X.Feng, K.Shankar, O.K.Varghese et al., Nano Lett., 8, 3781 (2008).

9. T.Ghoshal, S.Biswas, S.Kar et al., Nanotechnology, 19, 065606 (2008).

10. V.L.Karbivskiy, T.A.Korniyuk, Ukr. Bioorgan. Acta, 2, 7 (2009).

11. Niu Zhongwei et al., Nano Lett., 12, 3729 (2007).

12. Jung-Sun Lim et al., J. Nanomater., 4, 620505 (2010).

13. E.Dujardin et al., Nano Lett., 3, 413 (2003).

14. M.A.Correa-Duarte et al., Angew.Chem.Int. Ed., 44, 4375 (2005).

15. H.Wang et al., J.Am.Chem.Soc., 129, 12924 (2007).

16. Keith M. Bromley et al., J.Mater.Chem., 18, 4796 (2008).

17. V.L.Karbivskyy, V.Kh. Kasyanenko, N.A. Kurgan et al., Dopovidy NAN Ukraine, 3, 74 (2011).

18. V.L.Karbivskyy, N.A.Kurgan, V.Kh.Kasyanenko et al., Nanosistemy, Nanomaterialy, Nanotekhnologyy, 4, 665 (2014).

19. J.Fang, Ency Nanosci. \& Nanotechn., 5, 3953 (2004).

20. L.Y.Zhang et al., Nano-Micro Lett., 1, 49 (2009).

21. Tzu-Chun Tseng et al., Nature Chem., 2, 374 (2010).

22. J.Turkevich, P.S.Stevenson, J.Hiller, Discuss. Faraday Soc., 11, 55 (1951).

23. S.Majumder et al., J.Appl. Surf. Sci., 256, 438 (2009).

24. J.Ni et al., J. Thin Solid Films, 516, 7422 (2008).

25. K.Funato et al., J.Thin Solid Films, 518, 699 (2009). 